\title{
Magnetic, Electric and Structural Properties of Ni Substituted Co-Zn Ferrite Nanoparticles Synthesized by Sol-Gel Method.
}

\author{
R. B. Bhise ${ }^{1}$, S. M. Rathod ${ }^{2}$, A. K. Supekar ${ }^{3}$. \\ ${ }^{1}$ Department of Physics, JJT University, Jhunujhunu, Rajasthan (India). \\ ${ }^{2}$ Department of Physics, Abasaheb Garware College, Pune $(\mathrm{MH})$ \\ ${ }^{3}$ Department of Physics, Balasaheb.Jadhav.College, Ale( Pune ).
}

\begin{abstract}
Nickel substituted $\mathrm{Co}_{x} \mathrm{Zn}_{0.8-x} \mathrm{Fe}_{2} \mathrm{O}_{4}(x=0.2,0.5$ and 0.6) ferrite were synthesized by Sol-gel auto combustion method. The powders were sintering at $400^{\circ} \mathrm{C}$ and $700^{\circ} \mathrm{C}$ for $2 \mathrm{hrs}$ to densify properly. The samples were characterized by XRD, SEM and FTIR and Magnetic properties. The XRD used to analyze phase structure and lattice parameters. The FTIR spectra confirmed that synthesis material is ferrite. Morphology of ferrite powders were investigated by using SEM. Porosity of synthesis ferrite is measured. The saturation magnetization increases with increasing Co-Zn concentration. Resistivity of ferrite material is may be decreases due to vary concentration of Co and $\mathrm{Zn}$.
\end{abstract}

Keywords: Nanocrystalline, Structural Properties, Sol-gel Auto Combustion method, XRD, FTIR, SEM, Magnetization, Resistivity.

\section{Introduction}

Magnetic properties of Ni-Co-Zn have attracted attention because of their use at high frequency applications ${ }^{[1]}$. Because of high resistivity and low eddy current loss it also used as core material for transformer. $\mathrm{NiFe}_{2} \mathrm{O}_{4}$ (NF), $\mathrm{Co}_{\mathrm{Fe}_{2} \mathrm{O}_{4}}$ (CF) and $\mathrm{ZnFe}_{2} \mathrm{O}_{4}$ (ZF) shows good magnetic properties for technical application hence it is widely used in magnetic cores of read-write heads for high speed digital recording and production of electronic and magnetic components ${ }^{[2]}$. Which are depends on various parameters such as processing conditions, sintering temperature and time as well as on their chemical composition ${ }^{[3]}$. Researchers are used a variety of techniques including alternative sputtering technology, Pulse-Laser deposition, and spinspray plating etc to deposit film ${ }^{[4]}$. However most of them cannot be economically applied on a large scale because they required high vacuum system, complicated experimental steps and high reaction temperatures. In this study, chemical synthesis route called sol-gel auto combustion method has been applied synthesize NF, CF and $\mathrm{ZF}{ }^{[2-4]}$. This method is useful to achieve the fabrication of magnetic nanoferrites at low annealing temperature. The size and morphology of nano particles and their properties may be controlled by modifying the composition of the nanocomposites and by thermal treatment conditions ${ }^{[5]}$. Due to the small size of the nanocrystals, an important part of the atoms are located at the surface this is the reason why the sol-gel synthesis method gone on intensive development ${ }^{[6]}$. Upto this stage the research work on Ni-CO-Zn ferrite is very limited. The sol-gel method was used for synthesis of this nanoferrites material. This method involves hydrolysis ${ }^{[7-9]}$. In this paper we present a study of the magnetic and structural properties of $\mathrm{Ni}_{0.2} \mathrm{CO}_{0.2} \mathrm{Zn}_{0.6} \mathrm{Fe}_{2} \mathrm{O}_{4}$, $\mathrm{Ni}_{0.2} \mathrm{CO}_{0.5} \mathrm{Zn}_{0.3} \mathrm{Fe}_{2} \mathrm{O}_{4}$ and $\mathrm{Ni}_{0.2} \mathrm{CO}_{0.6} \mathrm{Zn}_{0.2} \mathrm{Fe}_{2} \mathrm{O}_{4}$ nanocomposites of different composition. The composition, crystal structure, morphology, and size distribution of Ni-Co-Zn ferrite nanocrystals can be controlled by adjusting the synthesis route and molar ratio of materials in the initial mixtures. The synthesized nano crystals have been characterized by XRD, SEM, FTIR, and Magnetic Properties presented below are the details of investigation.

\section{Experimental:}

The $\mathrm{Ni}_{0.2} \mathrm{CO}_{0.2} \mathrm{Zn}_{0.6} \mathrm{Fe}_{2} \mathrm{O}_{4}, \mathrm{Ni}_{0.2} \mathrm{CO}_{0.5} \mathrm{Zn}_{0.3} \mathrm{Fe}_{2} \mathrm{O}_{4}$ and $\mathrm{Ni}_{0.2} \mathrm{CO}_{0.6} \mathrm{Zn}_{0.2} \mathrm{Fe}_{2} \mathrm{O}_{4}$ ferrite powders were prepared by co-precipitation and hydro thermal technique using iron nitrate, zinc nitrate, cobalt nitrate, and nickel nitrate as reaction agent. To obtain $\mathrm{Ni}_{0.2} \mathrm{CO}_{0.2} \mathrm{Zn}_{0.6} \mathrm{Fe}_{2} \mathrm{O}_{4}, \mathrm{Ni}_{0.2} \mathrm{CO}_{0.5} \mathrm{Zn}_{0.3} \mathrm{Fe}_{2} \mathrm{O}_{4}$ and $\mathrm{Ni}_{0.2} \mathrm{CO}_{0.6} \mathrm{Zn}_{0.2} \mathrm{Fe}_{2} \mathrm{O}_{4}$ ferrite powders we have mixed AR grade iron nitrate, zinc nitrate, cobalt nitrate, and nickel nitrate with double distilled water. Citric acid was used as a chelating agent because it plays an important role in homogeneous mixture formation of metal cations. Reaction procedure was carried out in air atmosphere at room temperature. The composition was well shake and $\mathrm{pH}$ of solution is maintained as 7 by adding ammonia. The prepared solution was stirred on magnetic stirrer at low temperature $80^{\circ} \mathrm{C}$ to form a gel. The prepared ferrite samples were annealed for $400^{\circ} \mathrm{C}$ and $700^{\circ} \mathrm{C}$. The general chemical reaction involves in synthetic process can be written as

$(0.2) \mathrm{Ni}\left(\mathrm{NO}_{3}\right)_{2} \cdot 6 \mathrm{H}_{2} \mathrm{O}+(\mathrm{x}) \mathrm{Co}\left(\mathrm{NO}_{3}\right)_{2} \cdot 6 \mathrm{H}_{2} \mathrm{O}+(\mathrm{x}-0.8) \mathrm{Zn}\left(\mathrm{NO}_{3}\right)_{2} \cdot 6 \mathrm{H}_{2} \mathrm{O}+2 \mathrm{Fe}\left(\mathrm{NO}_{3}\right)_{3} .9 \mathrm{H}_{2} \mathrm{O}+3 \mathrm{C}_{6} \mathrm{H}_{8} \mathrm{O}_{7} \rightarrow \mathrm{Ni}_{0.2} \mathrm{CO}_{\mathrm{x}} \mathrm{Zn}_{\mathrm{x}-0.8}$ $\mathrm{Fe}_{2} \mathrm{O}_{4}+4 \mathrm{~N}_{2} \uparrow+18 \mathrm{CO}_{2} \uparrow+12 \mathrm{H}_{2} \mathrm{O}$. 
The synthesized nano crystalline samples were characterized by X-Ray Diffraction techniques at room temperature by using Philips powder X-Ray Diffractometer (model PW3710) with $\mathrm{CuK} \alpha$ radiations having wavelength $1.5406 \mathrm{~A}^{0}$. The morphological behavior of the investigated samples was determined by using Scanning Electron Microscopy (SEM) techniques (model HITACHI Japan). Fourier Transform Infrared (FTIR) spectra were recorded in the range of $4000-400 \mathrm{~cm}^{-1}$ at room temperature by using Brukar Spectrometry and magnetic properties for $\mathrm{Ni}$ substituted nanocrystalline $\mathrm{Ni}_{0.2} \mathrm{Co}_{\mathrm{x}} \mathrm{Zn}_{\mathrm{x}-0.8} \quad \mathrm{Fe}_{2} \mathrm{O}_{4}$ Spinal ferrite system sintered at $400^{\circ} \mathrm{C}$ and $700^{\circ} \mathrm{C}$ measured at room temperature with applied field of $6 \mathrm{KOe}$.

\subsection{X-Ray Diffraction.}

\section{Result And Discussion:}

To identify the possible formation of phase in Ni-Co-Zn ferrite an XRD analysis was done. The most intense peaks in all the specimens were found to match well with spherical spinel ferrite (JCPD). Lattice parameters and crystalline sizes of sintered ferrites specimens, evaluated by XRD analysis are shown in table (1) along with their composition, density, crystalline size, Porosity. There was a minor increase in lattice parameter which may be due to increasing concentration of $\mathrm{Co}$ and $\mathrm{Zn}$. But lattice parameter increases with in increasing annealing temperature $400^{\circ} \mathrm{C}$ to $700^{\circ} \mathrm{C}$. Decreasing densification may be due to the evolution of excess Co and $\mathrm{Zn}$ in the composition for Fe at room temp., $400^{\circ} \mathrm{C}$ and $700^{\circ} \mathrm{C}$ respectively. Decreasing in density may be due to vary with concentration of $\mathrm{Co}$ and $\mathrm{Zn}$. Porosity is increases due to increasing temperature at room temp., $400^{\circ} \mathrm{C}$ and $700^{\circ} \mathrm{C}$ respectively. The XRD patterns are shown as in fig $1(\mathrm{a}),(\mathrm{b})$, and (c).

Table No.1

\begin{tabular}{|c|c|c|c|c|c|}
\hline Compo & $\begin{array}{c}\text { Temperature } \\
{ }_{0}^{0} \mathrm{C}\end{array}$ & $\begin{array}{c}\text { Lattice } \\
\text { Constant } \\
\text { (a) } \mathbf{A}^{\mathbf{0}}\end{array}$ & $\begin{array}{c}\text { Inter } \\
\text { planer } \\
\text { Dist ( d } \\
\text { )nm }\end{array}$ & $\begin{array}{c}\text { Density } \\
\text { Dx. gm/cc }\end{array}$ & $\begin{array}{c}\text { Porosity } \\
\text { ( \% P ) }\end{array}$ \\
\hline \multirow{3}{*}{$\begin{array}{c}\text { I] } \mathrm{Ni}(\mathbf{0 . 2}) \mathrm{Co} \\
\mathrm{Zn}\end{array}$} & Room & 6.757 & 28.63 & $10.153 \times 10^{6}$ & 3.19 \\
\hline & 400 & 6.091 & 32.37 & $13.86 \times 10^{6}$ & 3.24 \\
\hline & 700 & 6.757 & 23.49 & $10.15 \times 10^{6}$ & 3.27 \\
\hline \multirow{3}{*}{$\begin{array}{c}\text { II] } \mathrm{Ni}(0.2) \\
\text { Co Zn }\end{array}$} & Room & 8.196 & 54.05 & $5.705 \times 10^{6}$ & 2.24 \\
\hline & 400 & 8.196 & 31.63 & $5.705 \times 10^{6}$ & 2.27 \\
\hline & 700 & 8.618 & 52.7 & $4.908 \times 10^{6}$ & 2.35 \\
\hline \multirow{3}{*}{$\begin{array}{l}\text { III] Ni(0.2) } \\
\text { CoZn }\end{array}$} & Room & 7.647 & 26.92 & $7.004 \times 10^{6}$ & 1.93 \\
\hline & 400 & 6.757 & 24.92 & $10.152 \times 10^{6}$ & 2.11 \\
\hline & 700 & 7.346 & 27.82 & $7.901 \times 10^{6}$ & 2.31 \\
\hline
\end{tabular}

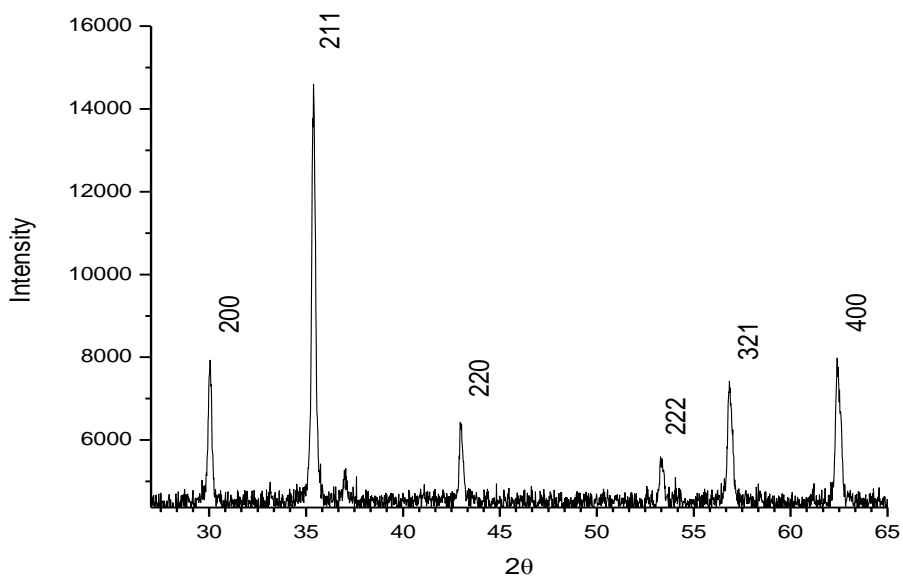

Fig-1(a) X-RD Pattern of Sintered $\mathrm{Ni}_{0.2} \mathrm{CO}_{0.2} \mathrm{Zn}_{0.6} \mathrm{Fe}_{2} \mathrm{O}_{4}$ Ferrites 


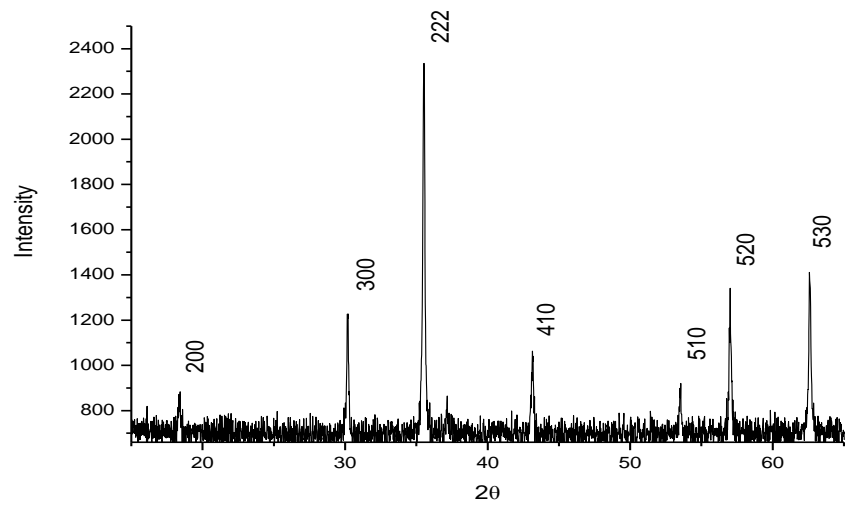

Fig-1(b) X-RD Pattern of Sintered

$\mathrm{Ni}_{0.2} \mathrm{CO}_{0.5} \mathrm{Zn}_{0.3} \mathrm{Fe}_{2} \mathrm{O}_{4}$ Ferrites

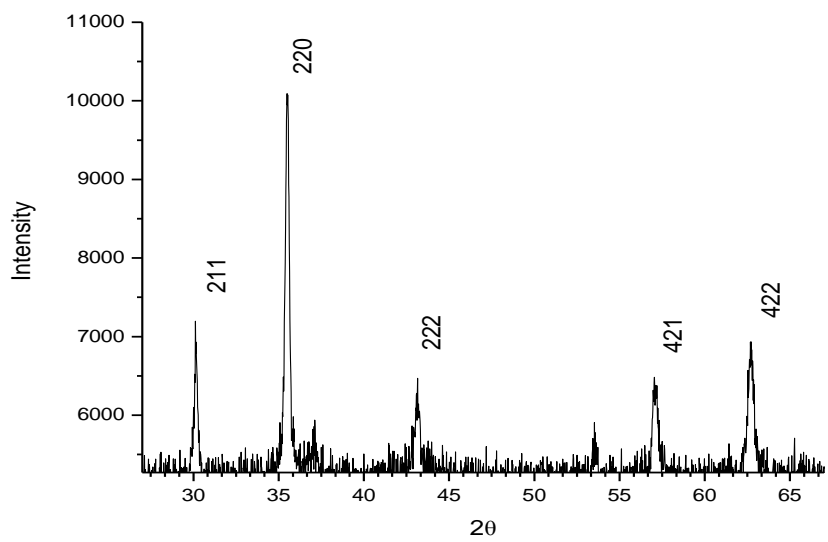

Fig-1(c) X-RD Pattern of Sintered

$\mathrm{Ni}_{0.2} \mathrm{CO}_{0.6} \mathrm{Zn}_{0.2} \mathrm{Fe}_{2} \mathrm{O}_{4}$ Ferrites

\subsection{FT-IR Spectra:}

In the present study $\mathrm{Ni}_{0.2} \mathrm{CO}_{0.2} \mathrm{Zn}_{0.6} \mathrm{Fe}_{2} \mathrm{O}_{4}, \mathrm{Ni}_{0.2} \mathrm{CO}_{0.5} \mathrm{Zn}_{0.3} \mathrm{Fe}_{2} \mathrm{O}_{4}$ and $\mathrm{Ni}_{0.2} \mathrm{CO}_{0.6} \mathrm{Zn}_{0.2} \mathrm{Fe}_{2} \mathrm{O}_{4}$ ferrite has been synthesized at room temperature, $400^{\circ} \mathrm{C}$, and $700^{\circ} \mathrm{C}$.The synthesis process is carried out using sol-gel auto combustion method. The citric acid was used a reducing agent in reaction. The of $\mathrm{Ni}_{0.2} \mathrm{CO}_{0.2} \mathrm{Zn}_{0.6} \mathrm{Fe}_{2} \mathrm{O}_{4} \mathrm{IR}$ curve fig2(a) of sintered powder shows strong absorption band $1619.912 \mathrm{Cm}^{-1}$ to $2339.23 \mathrm{Cm}^{-1}$ indicates N-H Bending structure, the strong absorption band at $2341.15 \mathrm{Cm}^{-1}$ indicating $\mathrm{C}$ triple bond $\mathrm{N}$ - Stretched. The band at 1715.46 $\mathrm{Cm}^{-1}$ indicating $\mathrm{C}-\mathrm{H}$ out of plane bending carbohydrates which is very weak and shifted to low frequency.

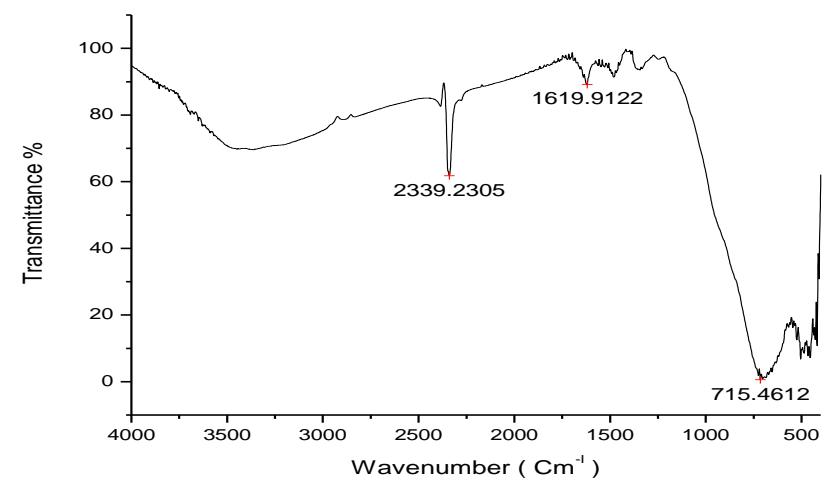

Fig-2(a) FT-IR Pattern of Sintered $\mathrm{Ni}_{0.2} \mathrm{CO}_{0.2} \mathrm{Zn}_{0.6} \mathrm{Fe}_{2} \mathrm{O}_{4}$ Ferrites. 


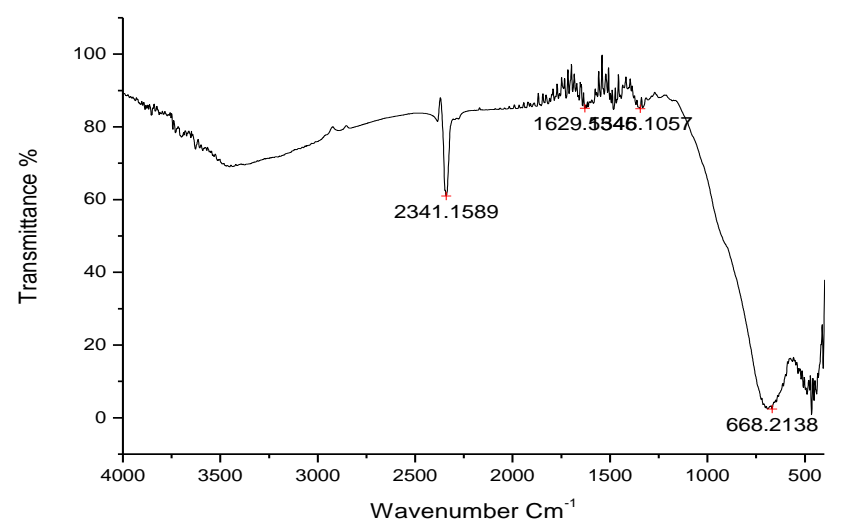

Fig-2(b) FT-IR Pattern of Sintered $\mathrm{Ni}_{0.2} \mathrm{CO}_{0.5} \mathrm{Zn}_{0.3} \mathrm{Fe}_{2} \mathrm{O}_{4}$ Ferrites.

The of $\mathrm{Ni}_{0.2} \mathrm{CO}_{0.5} \mathrm{Zn}_{0.3} \mathrm{Fe}_{2} \mathrm{O}_{4}$ IR curve fig2(b) of sintered powder shows strong absorption band $1345.10 \mathrm{Cm}^{-1}$ to $1629.55 \mathrm{Cm}^{-1}$ indicates $\mathrm{N}-\mathrm{H}$ Bending structure, the strong absorption band at $2341.15 \mathrm{Cm}^{-1}$ indicating $\mathrm{C}$ triple bond $\mathrm{N}$ - Stretched. The band at $668.21 \mathrm{Cm}^{-1}$ indicating $\mathrm{C}-\mathrm{H}$ out of plane bending carbohydrates which is very weak and shifted to low frequency.

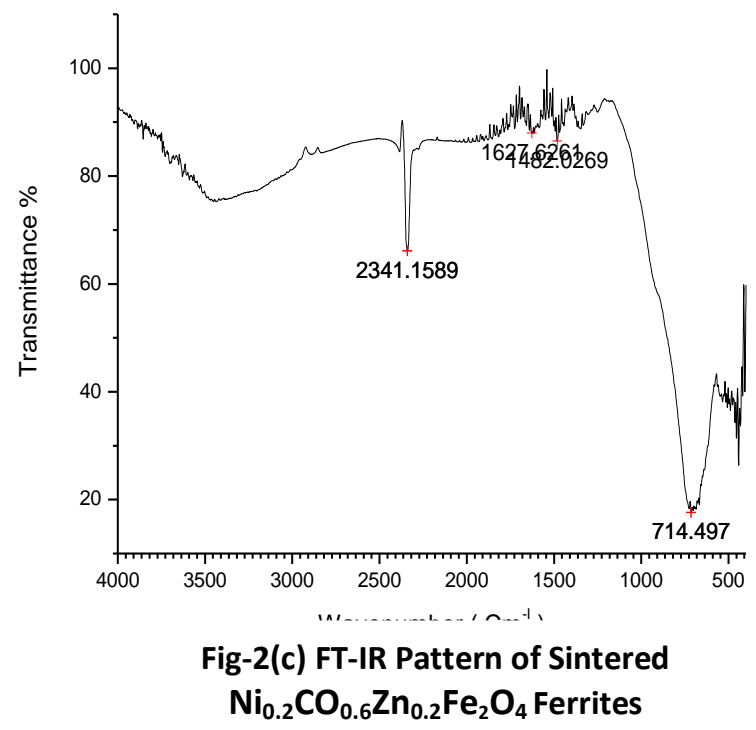

The of $\mathrm{Ni}_{0.2} \mathrm{CO}_{0.6} \mathrm{Zn}_{0.2} \mathrm{Fe}_{2} \mathrm{O}_{4}$ IR curve fig2(c) of sintered powder shows strong absorption band $14825.027 \mathrm{Cm}^{-1}$ to $1627.62 \mathrm{Cm}^{-1}$ indicates $\mathrm{N}-\mathrm{H}$ Bending structure, the strong absorption band at $2341.15 \mathrm{Cm}^{-1}$ indicating $\mathrm{C}$ triple bond $\mathrm{N}$ - Stretched. The band at $714.49 \mathrm{Cm}^{-1}$ indicating $\mathrm{C}-\mathrm{H}$ out of plane bending carbohydrates which is very weak and shifted to low frequency.

\subsection{SEM Morphology:}

Performing SEM we analyzed the structure of $\mathrm{Ni}_{0.6} \mathrm{CO}_{0.2} \mathrm{Zn}_{0.2} \mathrm{Fe}_{2} \mathrm{O}_{4}, \mathrm{Ni}_{0.2} \mathrm{CO}_{0.5} \mathrm{Zn}_{0.3} \mathrm{Fe}_{2} \mathrm{O}_{4}$ and $\mathrm{Ni}_{0.2} \mathrm{CO}_{0.6} \mathrm{Zn}_{0.2} \mathrm{Fe}_{2} \mathrm{O}_{4}$ shows typical morphology in fig3(a,b,c). For samples synthesized by sol-gel method the surface has compact structure with smallest particle size typically less than $60 \mathrm{~nm}$. The micrograph of samples sintered at $400^{\circ} \mathrm{C}$ and $700^{\circ} \mathrm{C}$ indicating that microstructure is completely form these temperature. The grain size increases with increase in temperature. 


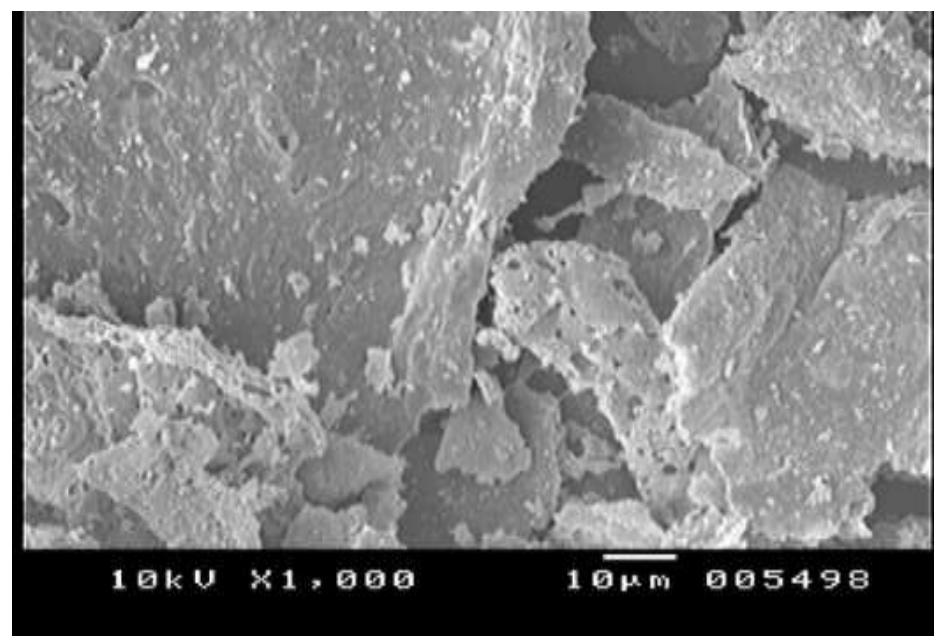

Fig-3(a)SEM Morphology of Sintered $\mathrm{Ni}_{0.2} \mathrm{CO}_{0.2} \mathrm{Zn}_{0.6} \mathrm{Fe}_{2} \mathrm{O}_{4}$ Ferrites.

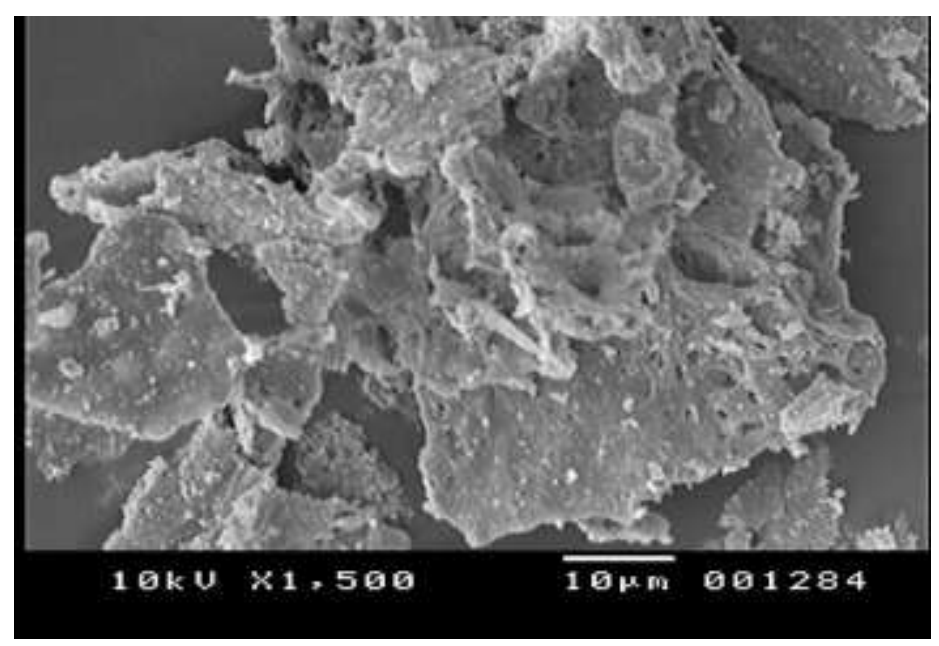

Fig-3(b) SEM Morphology of Sintered $\mathrm{Ni}_{0.2} \mathrm{CO}_{0.5} \mathrm{Zn}_{0.3} \mathrm{Fe}_{2} \mathrm{O}_{4}$ Ferrites.

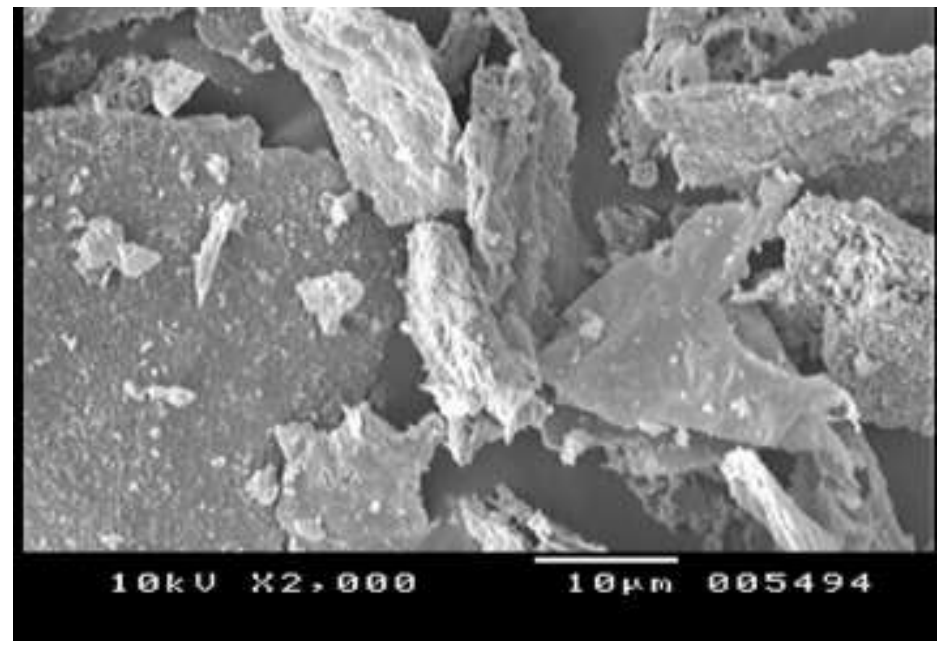

Fig-3(c) SEM Morphology of Sintered $\mathrm{Ni}_{0.2} \mathrm{CO}_{0.2} \mathrm{Zn}_{0.6} \mathrm{Fe}_{2} \mathrm{O}_{4}$ Ferrites 


\subsection{Magnetic Properties:}

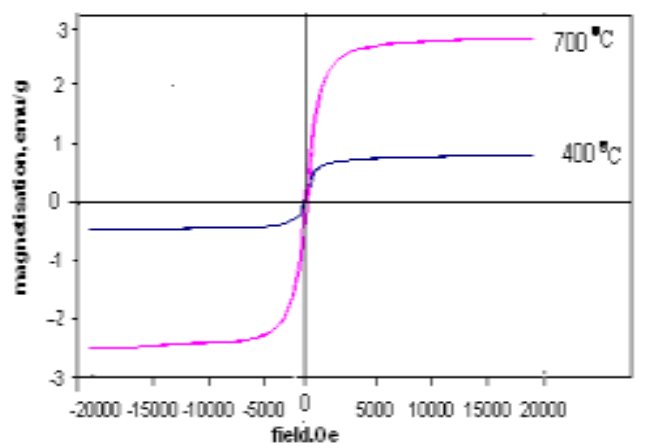

Fig.4 (a): Hysteresis loops of $\mathrm{Ni}_{0.2} \mathrm{Co}_{0.2} \mathrm{Zn}_{0.6}$ sintered at $400^{\circ} \mathrm{C}$ and $700^{\circ} \mathrm{C}$

Hysteresis loops of synthesized sample are shown in Fig.4 (a). Saturation magnetization value is 2.3 $\mathrm{emu} / \mathrm{g}$ for the sample sintered at $700^{\circ} \mathrm{C}$ and the same is $0.5 \mathrm{emu} / \mathrm{g}$ for the sample sintered at $400^{\circ} \mathrm{C}$. The increase of saturation magnetization with the increase in sintering temperature is an indication that the average magnetic domain size of the particle is increasing and the atomic spins are getting more and more aligned with the direction of the applied magnetic field. The increase in coercivity can result from an increase in particle size from super paramagnetic size to single domain size, the effect of surface anisotropy and thermal energies.

\subsection{Resistivity}

Sintered ferrite $\left(\mathrm{Ni}_{0.2} \mathrm{Co}_{0.2} \mathrm{Zn}_{0.6}\right) \mathrm{Fe}_{2} \mathrm{O}_{4}$ composition is optimize and pellet specimens were used to determine resistivity. Electrodes were painted on the surface of the sample using a conducting silver paste followed by curing at $300^{\circ} \mathrm{C}$ for $1 / 2 \mathrm{~h}$. The AC resistivity $\rho$ was analyzed by Impedance Analyzer Model $4192 \mathrm{~A}$, Hewlett Packard, USA. The Ferrite $\left(\mathrm{Ni}_{0.2} \mathrm{Co}_{0.2} \mathrm{Zn}_{0.6}\right) \mathrm{Fe}_{2} \mathrm{O}_{4}$ shows the resistivity of about $9.2 \mathrm{M} \Omega-\mathrm{cm}$ at $100 \mathrm{kHz}$ with frequency stability up to $\sim 10 \mathrm{MHz}$ The improved resistive properties of the composition might be due to the lowering of magnetostriction constant by $\mathrm{Ni}$ and $\mathrm{Co}-\mathrm{Zn}$ substitution and partly due to better densification. Due to different concentration of $\mathrm{Zn}$ and $\mathrm{Co}$ at constant $\mathrm{Ni}$ shows increase in interplaner distance for normal temperature to $400^{\circ} \mathrm{C}$ and again decrease for $400^{\circ} \mathrm{C}$ to $700^{\circ} \mathrm{C}$.

\section{Conclusion:}

The Ni-Co-Zn spinel ferrite nanoparticles were successfully synthesized by sol-gel auto combustion method. By varying the concentration of $\mathrm{CoFe}_{2} \mathrm{O}_{4}(\mathrm{CF})$, and $\mathrm{ZnFe}_{2} \mathrm{O}_{4}(\mathrm{ZF})$ at constant $\mathrm{Ni} \mathrm{Fe}_{2} \mathrm{O}_{4}(\mathrm{NF})$, there is increase in Lattice Constant, Inter planer distance, Porosity and decrease in Density at increasing temperature. The FTIR investigation shows strong absorption of $\mathrm{Co}$ and $\mathrm{Zn}$ ions. The nano crystalline natures confirm from SEM and XRD. SEM shows spherical spinal structure. XRD pattern confirm the formation of spherical spinel phase. The lattice parameters, Porosity and Density of ferrite materials are changes for different concentration and different temperature. The increase of saturation magnetization with the increase in sintering temperature is an indication that the average magnetic domain size of the particle is increasing and the atomic spins are getting more and more aligned with the direction of the applied magnetic field. The improved resistive properties of the composition might be due to the lowering of magnetostriction constant by $\mathrm{Ni}$ and $\mathrm{Co}-\mathrm{Zn}$ substitution and partly due to better densification.

\section{References:}

[1] S.Singhal,(2012), Str.Elt.Opt. Mag. Prop. Of Cr Subst. Co Zn nanoferrites, J.of Mol. Str.,1012,162-167.

[2] B.K.Chaughale(010), Prep. Char. Mag. Prop. Of nanocrystalline Ni Zn Ferrite, Sch.Res.Lib.2(2),388-395.

[3] K.C.Varma et al(2011), Strl, Microstrl.,Mag. Prop. Of NiCoMn Ferite thin film, J.Of Mag.and Mat.,323,3271-3275.

[4] K.H.Buschow,(1995),Hnd.bk Of Mag. Mat,8,198.

[5] M.Stefanescu,(2009), Prepn. Of Ni Zn Micro Comp. Powd. By S-G, j of Mat. Chem. And app. Phy.,113,342-348.

[6] P.K.Roy,(2008),Chr. Of nano Cryst. Ferritr, J. of Mat. Process Tec.,197,279-283.

[7] Xqi,J.Zhou,(2002), Key Eng. Mat.,593,224.

[8] R.Bhise S.Rathod, A.Supekar (2012 ) Synt. of Ni-Co-Zn ferrite nanoparticles, Int. J. of Basic and Appl. Res., 44(168-172).

[9] R.Bhise, S.Rathod, A.Supekar (2012), Char. of nanocryst. Ni-Co-Zn ferrite Powd., Golden Research Thoughts, Vol. 2 Iss. 4. 